\title{
HUBUNGAN OBESITAS, STRES DENGAN KEJADIAN HIPERTENSI PADA USIA DEWASA MUDA DI WILAYAHPUSKESMAS SUMBERSARI KOTA METRO
}

\author{
Dian Utama Pratiwi Putri ${ }^{1}$, M. Inggil Prasetyo ${ }^{2}$, Achmad Djamil $^{3}$ \\ 1,2,3Prodi Kesehatan Masyarakat, Universitas Mitra Indonesia
}

Email : dian@umitra.ac.id, Prasetyoinggil@gmail.com, abedjamil@gmail.com

\begin{abstract}
CORRELATION OF OBESITY, STRESS WITH HYPERTENSION IN YOUNG ADULTS AT SUMBERSARI'S PUBLIC HEALTH CENTER DISTRICT METRO CITY
\end{abstract}

Background: Hypertension is a condition of a person suffering from an increase in blood pressure above normal, namely systolic blood pressure $\geq 140 \mathrm{mmHg}$ and or diastolic blood pressure $\geq 90 \mathrm{mmHg}$. Based on data from the Sumbersari Metro City Health Center 2019, the number of hypertension cases increased from 833 people in 2018 to 1134 people. Most people with hypertension who visited Sumbersari Health Center were according to age groups, namely at the age of 20-44 years as many as 488 people.

purpose: To determine the relationship between obesity and stress and the incidence of hypertension in young adults in the area of Puskesmas Sumbersari, Metro City in 2020.

Methods: This was a quantitative study, cross sectional design. Independent variables (obesity, stress) and bound variables (hypertension). The population of this study were all 1427 patients who visited the public examination center at Sumbersari's Public Health center Metro City, 94 samples taken by accidental sampling. Direct data collection from respondents. Data analysis was univariate and bivariate (chi square) with an alpha of 0.05 .

Results: The results showed that from 94 respondents, $55(58.5 \%)$ of respondents had hypertension, $36(38.3 \%)$ of respondents were obese and as many as 54 (57.4\%) of respondents were in the stress category.

Conclusion: From the two independent variables studied, there was a relationship with hypertension, namely obesity ( $\mathrm{p}$-value $0.003: 95 \% \mathrm{Cl}$ ) with an OR value of 6.6 and stress ( $p$-value $0.000: 95 \% \mathrm{Cl}$ ) with an OR value of 5.8 . . It is recommended that health workers educate respondents to reduce stress such as listening to music, relaxation with aromatherapy or other coping mechanisms. Encouraging hypertensive patients to be able to lose weight, by adjusting the diet, exercising regularly every day and weighing each month.

Keywords: Obesity, Stress, Hypertension 


\section{INTISARI : HUBUNGAN OBESITAS, STRES DENGAN KEJADIAN HIPERTENSI PADA USIA DEWASA MUDA DI WILAYAH PUSKESMAS SUMBERSARI KOTA METRO}

Pendahuluan: Hipertensi merupakan suatu keadaan seseorang yang menderita peningkatan tekanan darah di atas normal, yaitu tekanan darah sistolik $\geq 140$ $\mathrm{mmHg}$ dan atau tekanan darah diastolik $\geq 90 \mathrm{mmHg}$. Berdasarkan data Puskesmas Sumbersari Kota Metro 2019 angka kasus hipertensi meningkat dari tahun 2018 sebanyak 833 orang menjadi 1134 orang. Penderita hipertensi yang berkunjung ke Puskesmas Sumbersari terbanyak menurut kelompok umur yaitu pada umur 20-44 tahun sebesar 488 orang.

Tujuan:Diketahui hubungan obesitas dan stres dengan kejadian hipertensi pada usia dewasa muda di wilayah Puskesmas Sumbersari Kota Metro Tahun 2020.

Metode: Jenispenelitiankuantitatif, desin / rancangancross sectional. Variabel bebas (obesitas, stres) dan Variabel Terikat (hipertensi). Populasi dari penelitian ini adalah seluruh pasien yang berkunjung ke balai pemeriksaan umum Puskesmas Sumbersari Kota Metro sebanyak 1427 orang, sampel sebanyak 94 diambil secara accidental sampling. Pengumpulan data langsungkepadaresponden. Analisis data secaraunivariatdanbivariat (chi square) dengan alfa 0,05.

Hasil Penelitian: Hasil penelitian didapatkan bahwa dari 94 responden, sebanyak $55(58,5 \%)$ responden mengalami hipertensi, sebanyak $36(38,3 \%)$ responden obesitas dan sebanyak $54(57,4 \%)$ responden dengan kategori stres.

Kesimpulan: Dari dua variabel bebas yang diteliti terdapat hubungan dengan kejaidan hipertensi yaitu variabel obesitas ( $p$-value 0,003 $: \mathrm{Cl} 95 \%$ ) dengan nilai OR 6,6 dan Stres ( $p$-value 0,000 :Cl 95\%) dengan nilai OR 5,8.Disarankan petugas kesehatan mengedukasi responden untuk mengurangi stres seperti mendengarkan musik, relaksasi dengan aroma terapi atau mekanisme koping lainnya. Menganjurkan pasien hipertensi untuk dapat mengurangi berat badan, dengan mengatur menu makan, berolahraga rutin setiap hari dan melakukan penimbangan berat badan setiap bulan.

Kata Kunci : Obesitas, Stres, Hipertensi

\section{PENDAHULUAN}

tekanan darah diperkirakan mengakibatkan 9,4 juta mortalitas serta memberikan tambahan 57 juta disability adjusted life years (WHO, 2014). kisaran 972 juta orang atau $26,4 \%$ orang di seluruh dunia menderita tekanan darah tinggi, angka ini bisa saja naik sampai $29,2 \%$ pada tahun 2025, dari 972 juta penderita tekanan darah tinggi, 333 juta terdapat pada negara maju lalu 639 sisanya ada pada negara berkembang, tak terkecuali Indonesia (Yonata, 2016).

Dari hasil riskesdas tahun 2018, angka kejadian hipertensi di Indonesia sebesar $34.1 \%$. Angka ini meningkat cukup tinggi dibandingkan hasil riskesdas tahun 2013 yang menyampaikan kejadian hipertensi menurut hasil penilaian tekanan darah pada masyarakat berusia 18 tahun lebih yaitu $25.8 \%$. Provinsi Kalimantan Selatan memiliki angka kejadian tertinggi sebesar 44,13\% kemudian oleh Jawa Barat sebesar 39,6\%, Kalimantan Timur sebesar 39,3\%. Provinsi Papua memiliki prevalensi hipertensi terendah sebesar $22,2 \%$, sedangkan Provinsi Lampung memiliki prevalensi hipertensi sebesar 29,94\% (Riskesdas, 2018).

Hasil pandu PTM Provinsi Lampung tahun 2018, Tekanan darah 
tinggi ialah penyakit tertinggi dari 10 besar penyakit PTM di seluruh Puskesmas Provinsi Lampung dengan jumlah kasus 546.625, diikuti diabetes melitus dengan jumlah kasus 182.469, dan obesitas dengan jumlah kasus 103.314 (Dinkes Provinsi Lampung, 2019). Prevalensi hipertensi terbesar berdasarkan hasil pengukuran terhadap penduduk umur 18 tahun keatas berdasarkan Kabupaten/Kota di Provinsi Lampung, pertama yaitu Kabupaten Way Kanan 10,69\%, Kabupaten Lampung Barat 10,08\% , Kabupaten Lampung Timur 9,60\%, Kota Metro 9,26\%, dan terendah Kabupaten Tanggamus 5,77\% (Riskesdas, 2018). Berdasarkan data tahunan dinas kesehatan Kota Metro dalam 10 besar penyakit dalam data morbiditas di puskesmas se kota Metro didapati hipertensi selalu menduduki peringkat pertama. Dalam 3 tahun terakhir pasien rawat jalan di Puskesmas dengan penyakit hipertensi mengalami penurunan dan kenaikan yaitu tahun 2016 sebesar 21\%, tahun 2017 sebesar 9,17\% dan terakhir 2018 mengalami kenaikan mencapai 24,01\%. Dari 11 puskesmas yang ada di Kota Metro tahun 2019, pasien hipertensi tertinggi berada pada wilayah kerja Puskesmas Metro sebesar 1354 orang, Puskesmas Yosomulyo 986 orang, Puskesmas Sumbersari sebesar 833 orang, dan terendah Puskesmas Purwosari sebanyak 277 orang. (Dinas Kesahtan Kota Metro, 2019)

Menurut laporan tahunan PTM di Puskesmas Sumbersari Kota Metro, diketahui bahwa kasus hipertensi menduduki peringkat pertama di bandingkan penyakit tidak menular lainnya, dimana tahun 2018 penderita hipertensi sebesar 833 orang, tahun 2019 sebesar 1134 orang dengan penderita hipertensi yang berkunjung ke Puskesmas Sumbersari terbanyak menurut kelompok umur yaitu pada umur 2044 tahun sebesar 488 orang, diikuti kelompok umur 45-54 tahun sebesar 373 orang, dan terendah 15-19 tahun sebesar 13 orang.

Penderita hipertensi yang sebagian besar dialami oleh masyarakat usia dewasa muda dibandingkan dengan usia lansia, dapat menjadi masalah kesehatan yang serius karena dapat mengganggu aktivitas dan dapat mengakibatkan penyakit gabungan yang berbahaya jika tidak terkendali dan tidak diupayakannya pencegahan dini. Tanda tanda penyakit lanjutan yang dapat terjadi seperti stroke, kerusakan mata, pembesaran otot jantung, sakit kepala, dan ginjal. (Sarumaha, 2018). Tekanan darah tinggi pada dewasa muda $50 \%$ diantaranya tidakmengetahui sebagai penderita,sehingga

merekacenderung untuk menjaditekanan darah tinggi berat karena tidak menghindaridan tidak mengerti penyebab risikonya, serta90\% ialah tekanan darah tinggi primer (Candradewi, 2015).

Usia dewasa muda merupakan tahapan pada pertumbuhan kehidupan manusia. Pertumbuhan kehidupan manusia dewasa terbagi menjadi tiga yaitu usia dewasa muda menggunakan usia antara 20 hingga 40 tahun, usia dewasa menengah menggunakan usia antara 40 hingga 65 tahun, dan usia dewasa akhir menggunakan usia diatas 65 tahun (Papalia dkk, 2010).

Penyebab tekanan darah tinggi bisa dibedakan menjadi dua faktor yaitu, faktor yang tidak bisa dikontrol berupa ras, umur, jenis kelamin, serta riwayat tekanan darah tinggi keluarga. Faktor yang dapat dikontrol misalnya obesitas, stres, merokok, kurang olahraga, kelebihan minum minuman beralkohol, kelebihan konsumsi garam. (Rohkuswara, 2016) 
Di wilayah Puskesmas Sumbersari berdasarkan laporan PTM tahun 2019, peningkatan kasus hipertensi seiring dengan peningkatan kasus obesitas dimana pada tahun 2018 kasus obesitas sebesar 115 orang menjadi 264 orang di tahun 2019. (PKM Sumbersari, 2019) Menurut Amanda (2018) Obesitas menaikkan tekanan darah dengan meningkatkan reabsorpsi natrium tubular ginjal, tekanan natriuresis terganggu, dan menambahkan volume melalui aktivasi sistem saraf simpatetik dan renin-angiotensinaldosteron sistem dan dengan kompresi fisik ginjal, terutama ketika ada kenaikan adipositas visceral.

Obesitas atau kegemukan bisa mengakibatkan penyakit tekanan darah tinggi dengan banyak cara, bisa dengan cara langsung maupun tidak langsung. Pada cara langsung obesitas dapat menyebabkan penin gkatan cardiac output sebab makin besar berat badan makin tinggi pula jumlah darah yang beredar hingga membuat curah jantung ikut mengalami kenaikan. Sedangkan secara tidak langsung dengan cara perangsangan aktivitas kerja saraf simpatis serta Renin Angiotensin Aldosteron System oleh perantara misalnya hormon, sitokin, adipokin, dan sebagainya. Salah satunya adalah hormon aldosteron yang terkait erat dengan penyimpanan air dan natrium sehingga volume darah meningkat.

Salah satu faktor yang mengakibatkan hipertensi lainnya adalah stres. ketika seseorang dalam keadaan stres, hormon adrenalin akan dilepaskan lalu mulai menaikkan tekanan darah dengan cara kontraksi arteri (vasokontriksi) serta menaikkan detak jantung. jika stres berlanjut, tekanan darah akan tetap tinggi sehingga orang itu akan mengalami (Suparta, 2018).
Usia dewasa muda menjadi masa perkembangan yang paling mudah mengalami stres, karena pada masa ini seseoarang berada pada masa paling produktif, kecenderungan untuk mengeksplor asi hal-hal baru, dan mulai menerima tuntutan-tuntutan dari orang lain dan lingkungan sekitarnya yang pada akhirnya berdampak pada kelelahan fisik dan mental (Manita, 2019)

Menurut hasil prasurvey yang dilakukan pada tanggal 28 April 2020 di Puskesmas Sumbersari Kota Metro, diketahui dari 20 orang yang berobat sebanyak 12 orang penderita hipertensi, sebanyak 5 orang dengan diagnose dyspepsia, dan 3 orang diagnose diare. Dari 12 penderita hipertensi tersebut sebanyak 7 orang $(58,3 \%)$ mengalami obesitas dan sebanyak 5 orang $(41,6 \%)$ tidak mengalami obesitas. Dari 12 orang tersebut ketika dilakukan wawancara dengan menggunakan beberapa pertanyaan skala Depression Anxiety and Stress Scale untuk mengetahui tingkat stress, mengungkapkan bahwa sebanyak 4 orang menunjukkan gejala stress seperti Menjadi marah karena halhal kecil/sepele, Kesulitan untuk relaksasi/bersantai, Cenderung bereaksi berlebihan pada situasi, gampang merasa kesal, Merasabanyak menghabiskan energi karena cemas, Tidak sabaran, Mudah tersinggung, Sulit untuk beristirahat, Mudah marah, Kesulitan untuk tenang setelah sesuatu yang mengganggu, Sulit $m$ entoleransigangguan-gangguanpada hal yang sedang dilaksanakan, Berada pada kondisi tegang, Tidak dapat memaafkan hal apapun yang menghalangi untuk menyelesaikan hal yang sedang dilakukan, gampang gelisah.

Dilihat dari uraian di atas, peneliti tertarik untuk melakukan 
penelitian yang berjudul "Hubungan Obesitas, stres Dengan Kejadian Hipertensi Pada Usia Dewasa Muda Di Wilayah Puskesmas Sumbersari Kota Metro Tahun 2020"

\section{METODE PENELITIAN}

Dalam penelitian ini menggunakan jenis penelitian kuantitatif.

Populasi yang digunakan dalam penelitian ini merupakan pasien yang melakukan pengobatan di wilayah Puskesmas Sumbersari Kota Metro dengan rata - rata kunjungan perbulan sebanyak1427 orang. Sampel sebanyak 94 diambil secara accidental sampling.

Desain dalam penelitian ini menggunakan analitik dengan pendekatan Cross sectional, yang merupakan jenis penelitian yang menekankan pada waktu pengukuran / observasi data variabel independen serta dependen hanya satukali, dalam satu waktu. Analisis bivariat menggunakan uji chi- square dan menggunakan aplikasi SPSS. (Sugiyono, 2017).

HASIL

Analisi Univariat

Tabel 1

Distribusi frekuensi ObesitasDi Wilayah Puskesmas Sumbersari Kota Metro Tahun 2020

\begin{tabular}{clrr}
\hline Variabel & \multicolumn{1}{c}{ Kategori } & Frekuensi & Persentase (\%) \\
\hline Obesitas & Obesitas & 36 & 38,3 \\
& tidak Obesitas & 58 & 61,7 \\
\hline & Total & 94 & 100,0 \\
\hline
\end{tabular}

Berdasarkan tabel 1.1 didapatkan hasil bahwa dari 94 responden, ditemukan sebanyak $36 \quad(38,3 \%)$ responden mengalami obesitas dan sebanyak $58(61,7 \%)$ responden tidak mengalami obesitas.

Tabel 2

Distribusi frekuensi stress Di Wilayah Puskesmas Sumbersari Kota Metro

\begin{tabular}{llrr}
\hline Variabel & \multicolumn{1}{c}{ Kategori } & Frekuensi & \multicolumn{1}{c}{$\begin{array}{c}\text { Persentase } \\
\text { (\%) }\end{array}$} \\
\hline stress & Stress & 54 & 57,4 \\
& Tidak stress & 40 & 42,6 \\
\hline \multicolumn{2}{c}{ Total } & 94 & 100,0 \\
\hline
\end{tabular}

Berdasarkan tabel 2 diketahui bahwa sebagian besar reponden mengalami stress berjumlah $54 \quad(57,4 \%)$ responden dan sebanyak $40(42,6 \%)$ responden tidak mengalami stress. 
Tabel 3

Distribusi frekuensi hipertensiDi Wilayah Puskesmas Sumbersari Kota Metro

\begin{tabular}{clrr}
\hline Variabel & \multicolumn{1}{c}{ Kategori } & Frekuensi & \multicolumn{1}{c}{$\begin{array}{c}\text { Persentase } \\
(\%)\end{array}$} \\
\hline Hipertensi & Hipertensi & 55 & 58,5 \\
& Tidak hipertensi & 39 & 41,5 \\
\hline & Total & 94 & 100,0 \\
\hline
\end{tabular}

Berdasarkan tabel 3 ditemukan sebagian besar $55(58,5 \%)$ menderita hipertensi dan sebanyak $39(41,5 \%)$ tidak menderita hipertensi.

Analisis Bivariat

Tabel 4

Hubungan Obesitas Dengan Kejadian Hipertensi Usia dewasa muda Di Wilayah Puskesmas Sumbersari Kota Metro

\begin{tabular}{|c|c|c|c|c|c|c|c|c|}
\hline \multirow{3}{*}{ obesitas } & \multicolumn{4}{|c|}{ Hipertensi } & \multirow{3}{*}{$\mathrm{n}$} & \multirow{3}{*}{$\%$} & \multirow{3}{*}{$\begin{array}{c}p- \\
\text { value }\end{array}$} & \multirow{3}{*}{$\begin{array}{c}\text { OR } \\
95 \% \mathrm{Cl}\end{array}$} \\
\hline & \multicolumn{2}{|c|}{ Hipertensi } & \multicolumn{2}{|c|}{$\begin{array}{c}\text { Tidak } \\
\text { hipertensi }\end{array}$} & & & & \\
\hline & $n$ & $\%$ & $\mathrm{n}$ & $\%$ & & & & \\
\hline Obesitas & 30 & 83,3 & 6 & 16,7 & 36 & 100,0 & & 6,600 \\
\hline $\begin{array}{l}\text { Tidak } \\
\text { obesitas }\end{array}$ & 25 & 43,1 & 33 & 56,9 & 58 & 10 & 0,003 & $\begin{array}{l}(2,382- \\
18,258)\end{array}$ \\
\hline Total & 55 & 58,5 & 39 & 41,5 & 94 & 100,0 & & \\
\hline
\end{tabular}

Berdasarkan tabel 1.2 dari hasil penelitian diketahui bahwa proporsi kejadian hipertensi lebih banyak pada responden yang mengalami obesitas sebesar $30(83,3 \%)$ orang dibandingkan dengan responden yang tidak mengalami obesitas 25 $(43,1 \%)$ orang. Hasil uji statistik diperoleh $p$-value $=0,003$ yang berarti $p<a \quad(0,05)$, maka dapat disimpulkan bahwa terdapat hubungan obesitas dengan kejadian hipertensi usia dewasa muda di wilayah Puskesmas Sumbersari Kota Metro Tahun 2020, dengan nilai OR 6,600 artinya responden dengan obesitas memiliki peluang 6,6 kali mengalami hipertensi apabila dibandingkan dengan responden tidak obesitas.

Tabel 1.5

Hubungan Stres Dengan Kejadian Hipertensi Usia dewasa muda Di Wilayah Puskesmas Sumbersari Kota Metro Tahun 2020 Hipertensi

\begin{tabular}{|c|c|c|c|c|c|c|c|c|}
\hline \multirow[t]{2}{*}{ Stress } & \multicolumn{2}{|c|}{ Hipertensi } & \multicolumn{2}{|c|}{$\begin{array}{c}\text { Tidak } \\
\text { hipertensi }\end{array}$} & \multirow[t]{2}{*}{$\mathrm{n}$} & \multirow[t]{2}{*}{$\%$} & \multirow[t]{2}{*}{$\begin{array}{c}p- \\
\text { value }\end{array}$} & \multirow[t]{2}{*}{$\begin{array}{c}\text { OR } \\
95 \% \mathrm{Cl}\end{array}$} \\
\hline & $n$ & $\%$ & $\mathrm{n}$ & $\%$ & & & & \\
\hline Stress & 41 & 75,9 & 13 & 24,1 & 54 & 100,0 & & 5,857 \\
\hline $\begin{array}{l}\text { Tidak } \\
\text { stress }\end{array}$ & 14 & 35,0 & 26 & 65,0 & 40 & ,0 & 0,000 & $\begin{array}{l}(2,380- \\
14,417)\end{array}$ \\
\hline Total & 55 & 58,5 & 39 & 41,5 & 94 & 100,0 & & \\
\hline
\end{tabular}


Berdasarkan tabel 1.5 dari hasil penelitian diketahui bahwa proporsi kejadian hipertensi lebih banyak pada responden yang mengalami stress sebesar $41(75,9 \%)$ orang dibandingkan dengan responden yang tidak mengalami stress 14 $(35,0 \%)$ orang. Hasil uji statistik diperoleh $p$-value $=0,000$ yang berarti $p<a \quad(0,05)$, maka dapat

\section{PEMBAHASAN}

Berdasarkan hasil penelitian, diketahui bahwa dari 94 responden, terdapat $36 \quad(38,3 \%)$ responden mengalami obesitas dan sebanyak 58 $(61,7 \%)$ responden tidak mengalami obesitas di wilayah Puskesmas Sumbersari Kota Mtero tahun 2020.

Menurut Asdie (2012) Obesitas dapat menimbulkanterjadinya hipertensi melalui berbagaimekanisme, baik secara langsungmaupun tidak langsung. Secara langsungobesitas dapat menyebabkanpeningkatancardiac output karenamakin besar massa tubuh makin banyakpula jumlah darah yang beredarsehingga curah jantung ikut meningkat.Sedangkan secara tidak langsungmelalui perangsangan aktivitas systemsaraf simpatis dan Renin AngiotensinAldosteron System (RAAS) olehmediator-mediator seperti hormon,sitokin, adipokin, dsb. Salah satunyaadalah hormon aldosteron yang terkait.erat dengan retensi air dan natriumsehingga volume darah meningkat

Penelitian Sulastri (2015) dengan judul hubungan kejadian obesitas disertai hipertensi dilakukan terhadap masyarakat etnik Minangkabau pada 8 kelurahan di kota Padang. Penelitian ini merupakan studi komparatif menggunakan desain cross sectional study, dengan jumlah sampel 204 orang. Hasil penelitian mendapatkan disimpulkan bahwa terdapat hubungan stress Dengan Kejadian hipertensi usia dewasa muda di wilayah Puskesmas Sumbersari Kota Metro tahun 2020, dengan nilai OR 5,857 artinya responden denganstressmemiliki peluang 5,8 kali mengalami hipertensi apabila dibandingkan dengan responden tidak stress.

bahwa lebih dari separuh penderita hipertensi mengalami obesitas $(56,6 \%)$ dan obesitas sentral $(54,9 \%)$ .Penelitian Yanti (2018) dengan judul Hubungan Obesitas Dengan Kejadian Hipertensi Pada Usia Dewasadapat dilihat dari 53 responden didapatkan 34 responden $(64,2 \%)$ mengalami obesitas dan 42 responden $(79,2 \%)$ mengalami hipertensi

Menurut pendapat peneliti, untuk penderita hipertensi dapat memfokuskan pada penurunan berat badan sebagai penanganan utama untuk pasien obesitas selain dari pemberian terapi farmakologi. Dengan adanya penurunan berat badan diharapkan dapat menurunkan tekanan darah, dikarenakan kerja jantung untuk memompa darah dapat menurun.

\section{a. Stres}

Berdasarkan hasil penelitian, diketahui sebagian besar responden di wilayah Puskesmas Sumbersari Kota Metro tahun 2020 mengalami stres yaitu sebanyak $54 \quad(57,4 \%)$ responden dan yang tidak mengalami stress sebanyak $40 \quad(42,6 \%)$ responden

Stres adalah respon tubuh yang sifatnya nonspesifik terhadap setiap tuntutan beban atasnya. Setelah seseorang mengalami stress, maka akan mengalami gangguan pada satu atau lebih organ tubuh sehingga yang bersangkutan tidak lagi dapat 
menjalankan fungsi pekerjaannya dengan baik, maka disebut mengalami distres (Hawari 2015).

Penelitian Islami (2015) dengan hasil didapatkan responden yang menderita hipertensi didapatkan 33 responden $(70,2 \%)$ yang mengalami stres dan 14 responden $(29,8 \%)$ yang tidak mengalami stres. Sedangkan responden yang tidak menderita hipertensi didapatkan 8 responden (17\%) mengalami stres dan 39 responden (31\%) tidak mengalami stres.

Menurut pendapat peneliti, stres dapat menimbulkan risiko hipertensi, sehingga perlu adanya motivasi yang kuat untuk bisa mengontrol stres pada penderita hipertensi.

\section{b. Hipertensi}

Berdasarkan hasil penelitian diketahui sebagian besar menderita hipertensi yaitu sebanyak $55(58,5 \%)$ responden sedangkan sebanyak 39 $(41,5 \%)$ responden tidak menderita hipertensi di wilayah Puskesmas Sumbersari Kota Metro tahun 2020.

Menurut Price \& Lorraine (2012) hipertensi merupakan suatu keadaan seseorang mengalami peningkatan tekanan darah di atas normal, yaitu tekanan darah sistolik $\geq 140 \mathrm{mmHg}$ dan atau tekanan darah diastolik $\geq$ $90 \mathrm{mmHg}$. Meningkatnya kejadian hipertensi cenderung terjadi pada orang dengan faktor risiko seperti keturunan, usia, konsumsi garam berlebih, kolesterol, obesitas, dan stress. Hipertensi mempunyai gejala umum yang di timbulkan seperti pusing, mudah lelah,sakit kepala, rasa berat ditengkuk, sukar tidur, mata berkunang-kunang (Asdie, 2012).

Penelitian Arifin (2016) Hasil Penelitian dengan uji chisquaremenyatakan bahwa terdapat hubungan yang bermakna antara genetik $(p=0,019)$, obesitas $(p=0,017)$, dan tingkat stress $(p<$
0,0001) dengan kejadian hipertensi. Sedangkan jenis kelamin,merokok, dan konsumsi alkohol tidak terdapat hubungan yang bermakna dengan kejadian hipertensi

Menurut peneliti gaya hidup yangtidak sehat, dapat menyebabkan terjadinyapenyakit hipertensi, misalnya; dari makanan,aktifitas fisik, dan stres.Hal-hal tersebut dapat menyebabkanterjadinya hipertensi dimana stres dapatmerusak jantung dan sirkulasi darah danmeningkatkan risiko penyakit jantung danstroke, merawat badan tetap ideal yaitu aktifberaktivitas dapat melindungi dari penyakithipertensi, selain itu aktif beraktifitas secarateratur dapat membantu menurunkan tekanandarah dan memperbesar penurunan beratbadan.

\section{Hubungan obesitas dengan kejadian hipertensi}

Berdasarkan hasil penelitian terdapat hubungan obesitas dengan kejadian hipertensi usia dewasa muda di wilayah Puskesmas Sumbersari Kota Metro tahun 2020, dengan nilai OR 6,600 artinya responden denganobesitas memiliki peluang 6,6 kali mengalami hipertensi jika dibandingkan dengan responden tidak obesitas

Obesitas diartikan sebagai suatu keadaan dimana terjadi penumpukanlemak yang berlebihan di jaringan lemak tubuh, sertabisa menyebabkan terjadinya beberapa penyakit. Parameter yang umum digunakan untuk menentukan keadaan tersebut adalah indeks massa tubuh seseorang $27 \mathrm{~kg} / \mathrm{m} 2$. Selain itu kelebihan berat badan juga meningkatkan kadar insulin dalam darah. Peningkatan insulin ini menyebabkan retensi natrium pada ginjal sehingga tekanan darah ikut naik (Arisman, 2012). obesitas cenderung terjadi kenaikkan volume plasma akan meningkatkan curah 
jantung yang menyebabkannaiknya tekanan darah, sedangkan resistensi pembuluh darah sistemik di obesitas umumnya normal dan tidak berperan pada peningkatan tekanan darah(Kapojos, 2015).

Sejalan dengan penelitian Sulastri (2015) Hasil uji statistik chisquare menunjukkan ada hubunganyang bermakna antara obesitasdengan kejadian hipertensi ( $p$ value $<0,05)$ dengan nilai $O R=2,72$, artinyaresponden yang mengalami obesitas berisiko 2,72 kali terkena hipertensi dibanding responden yangtidak obesitas.Lestari (2015) Analisis Faktor Risiko Kebiasaan Mengkonsumsi Garam, obesitas, aktivitas fisik Dan Minum Kopi Terhadap Kejadian Hipertensi Pada Nelayan Suku Bajo Di Pulau Tasipi Kabupaten Muna Barat Tahun 2015 Hasil penelitian menunjukkan bahwa secara signifikan semua variabel independen merupakan faktor risiko kejadian penyakit hipertensi di Pulau Tasipi yaitu obesitas (OR=7,917 ; $\mathrm{p}=0.00$ ). Yanti (2018) Hubungan Obesitas Dengan Kejadian Hipertensi Pada Usia Dewasa Hasil penelitian menunjukkan nilai uji statistik dengan nilaip value $=0,03 \backslash(<0,05)$, hal ini menunjukkan ada hubungan obesitas dengan kejadian hipertensi pada usia dewasa, di mana nilai $\mathrm{OR}=4,375$, yang artinya pasien dewasa akan beresiko atau berpeluang mengalami hipertensi sebanyak 4,375 kali.

Menurut pendapat peneliti, obesitas merupakan salah satu dari faktor risiko hipertensi. Seseorang yang memiliki berat badan berlebih atau mengalami obesitas akan membutuhkan lebih banyak darah untuk menyuplai oksigen dan makanan ke jaringan tubuhnya, sehingga volume darah yang beredar melalui pembuluh darah meningkat, curah jantung ikut meningkat dan akhirnya tekanan darah ikut meningkat. Penderita hipertensi yang termasuk dalam kategori obesitas disarankan untuk menjaga pola hidup sehat dengan memperhatikan diet pada makanan, mengurangi sumber karbohidrat, memperhatikan keseimbangan asupan makanan, olahraga dengan teratur dan rutin, membuat program pengurangan berat badan menjadi berat badan ideal dimana penderita dapat meminta saran kepada ahli gizi yang ada di Puskesmas. peran serta petugas tenaga kesehatan masyarakat untuk meningkatkan penyuluhan.

\section{Hubungan stres penderita penyakit hipertensi dengan kejadian hipertensi}

Berdasarkan hasil penelitian dapat dilihat bahwa kejadian hipertensi lebih banyak terjadi pada responden yang mengalami stress dengan hasil uji statistik diperoleh $p$ value $=0,000$ yang berarti $p<a$ $(0,05)$, maka dapat disimpulkan bahwa ada hubungan stres dengan kejadian hipertensi usia dewasa muda di wilayah Puskesmas Sumbersari Kota Metro tahun 2020, dengan nilai OR 5,857 artinya responden dengan stress memiliki peluang 5,8 kali memiliki hipertensi jika dibandingkan dengan responden dengan tidak stress

Menurut Hawari (2015) Stres adalah respon tubuh yang sifatnya nonspesifik terhadap setiap tuntutan beban atasnya. Bila seseorang setelah mengalami stres mengalami gangguan pada satu atau lebih organ tubuh sehingga yang bersangkutan tidak lagi dapat menjalankan fungsi pekerjaannya dengan baik, maka disebut mengalami distress. Stres dapat meningkatkan pembentukan senyawa yang membahayakan dalam tubuh, mempercepat pompa kerja jantung untuk mengalirkan darah keseluruh tubuh sehingga tekanan darah meningkat dan dapat menyebabkan terjadinya serangan 
jantung dan stroke (Setyawan, 2017). Hubungan antara stress dengan terjadinya hipertensi diduga melalui aktivitas saraf simpatis yang dapat meningkatkan tekanan darah secara bertahap. Apabila stress menjadi berkepanjangan dapat berakibat tekanan darah menjadi tetap tinggi. Hipertensi akan muncul pada orang yang sering stres dan mengalami ketegangan pikiran yang berlarut-larut (Muawanah, 2015).

Penelitian Situmorang (2020) dengan hasil penelitian didapatkan Dari 40 responden terdapat hubungan yang signifikan antara tingkat stres dengan hipertensi dengan nilai sistolik dan juga diastolik dengan nilai $p<0,05$. Peneltian Arifin (2016) faktor-faktor yang berhubungan dengan hipertensi di wilayah kerja UPT Puskesmas Petang I, Kabupaten Badung. Hasil Penelitian dengan uji chi-square dan Fisher Exact Test menyatakan bahwa terdapat hubungan yang bermakna antara tingkat stress $(p<$ 0,0001 ) dengan kejadian hipertensi.

Berdasarkan hasil penelitian diketahui dari 54 responden yang stres, sebanyak $13 \quad(10,8 \%)$ responden tidak hipertensi hal ini dimungkinkan karena setiap orang berbeda dalam penanganan stress, ada yang dapat menanggulangi secara langsung dari stres yang dihadapi namun ada pula yang tidak dapat mengontrol diri saat sedang stres. Dari 40 responden yang tidak stress sebanyak $14 \quad(38,6 \%)$ menerapkan gaya hidup sehat sehingga dapat mengurangi berat badan yang berlebih dan mengurangi stres selain itu penderita hipertensi

\section{KESIMPULAN}

Berdasarkan hasil penelitian yang didapat, maka dapat disimpulkan pada penelitian ini yaitu: Ada hubungan Obesitas kejadian hipertensi usia dewasa muda di wilayah Puskesmas Sumbersari Kota responden hipertensi, menurut pendapat peneliti hal ini dimungkinkan adanya faktor lain yang menyebabkan hipertensi sehingga walaupun responden termasuk dalam kelompok tidak stress namun responden mengalami hipertensi seperti kemungkinan responden merupakan kelompok obesitas, atau adanya faktor lain yang tidak diambil dalam penelitian ini seperti gaya hidup yang lain, antara lain merokok, konsumsi asupan garam tinggi, adanya keturunan sehingga responden mengalami hipertensi.

Menurut pendapat peneliti, bagi responden untuk menjaga pola hidup sehat dengan mengkonsumsi gizi seimbang, aktifitas olahraga rutin, menghindari stres hal- hal seperti ini harus dapat dilakukan oleh pasien untuk menghindari hipertensi lanjut yang dapat menyebabkan dampak lebih buruk atau untuk mencegah terjadinya hipertensi bagi yang belum terkena hipertensi. dibutuhkan kedisiplinan seseorang untuk meningkatkan derajat kesehatannya, peran tenaga promosi kesehatan sebagai educator harus dapat meningkatkan pengetahuan responden dengan memberikan pendidikan kesehatan berupa gaya hidup sehat sehingga responden dapat mengontrol hipertensi yang diderita dan memotivasi responden yang mengalami hipertensi untuk patuh dalam mengkonsumsi makanan, harus patuh dalam mengkonsumsi obat.

Metro tahun 2020 ( $p$-value 0,003 : OR 6,600 ). Ada hubungan stres dengan kejadian hipertensi usia dewasa muda di wilayah Puskesmas Sumbersari Kota Metro tahun 2020 ( $p$-value 0,000 : OR 5,857). Diketahui dari 55 penderita hipertensi 
sebanyak 30 orang $(54,5 \%)$ responden mengalami obesitas dan 25 orang $(45,5 \%)$ responden tidak obesitas.

\section{DAFTAR PUSTAKA}

Arisman, MB., Dr. (2012). Buku Ajar Ilmu Gizi: Gizi dalam Daur Kehidupan.Jakrta:EGC

Arikunto, Suharsimi. (2013). Prosedur penelitian suatu pendekatan praktik. Jakarta: PT Rineka Cipta.

Asdie Ahmad Horrison (ed) edisi Indonesia. K. J. Isselbacher, E. Braunwald, J.D. Wilson, J.B. Martin, A.S. Fauci, D.L. (2012). Prinsip-prinsip Ilmu Penyakit Dalam Volume 3Edisi 13. Jakarta : EGC.

Badan Penelitian Dan Pengembangan Kesehatan Kementerian Kesehatan RI. (2018). Riset Kesehatan Dasar 2018. Jakarta

Dinas Kesehatan Kota Metro. (2017) . Profil kesehatan Kota Metro tahun 2016.Lampung

Dinas Kesehatan Kota Metro. (2018) . Profil kesehatan Kota Metro tahun 2017. Lampung

Dinas Kesehatan Provinsi Lampung. (2019) . Profil kesehatan Lampung tahun 2018. Lampung

Departemen Kesehatan, RI. (2010). Pedoman Teknis Penemuan Dan Tatalaksana Penyakit Hipertensi. Diakses di http://www.depkes.go.id/ind ex.php /berita/pressrelease/1909-masalahhipertensi-stroke-diindonesia.html diakses tanggal 3 maret 2018

Hastono. (2016). Analisis Data Pada Bidang Kesehatan. P.T Rineka Cipta. Jakarta.

Hawari, Dadang. (2015). Manajemen Stres Cemas dan Depresi. Jakarta. FKUI
Islami, Katerin Indah. (2015). Hubungan Antara Stres Dengan Hipertensi Pada Pasien Rawat Jalan Di Puskesmas Rapak Mahang Kabupaten Kutai Kartanegara Provinsi Kalimantan Timur http://eprints.ums.ac.id/ 39382/diakses pada tangggal 3 Maret 2020

James., Ma, M., McNeill, M., Charles, D., McDonough, S., Crosbie, J., Oliver, L.,McGoldrick, C. (2014). Adaptive Virtual Reality Games for Rehabilitation of Motor Disorders. In Stephanidis, C., editor, Universal Access in HumanComputerlnteraction. Ambient Interaction, volume 4555 of Lecture Notes inComputer Science, 681-690. Springer. Diakses tanggal 3 Maret 2020

Kapojos. (2015). Hubungan obesitas dengan http: / /INASH.org.com /2017/02 / diakses pada tangggal 3 Maret 2020

Kementrian Kesehatan RI(2017). Profil Kesehatan Indonesia 2016. Jakarta

Kementrian Kesehatan RI(2016). Pusat data dan informasi: Hipertensi. Jakarta

Notoatmodjo. (2012). Metodologi Penelitian Kesehatan. P.T Rineka Cipta. Jakarta.

Sugiyono, Dr., (2017). Metode penelitian Kuantitatif Kualitatif dan R\&D, Penerbit ALFABETA. Bandung

Sari, Yanita Nur Indah. (2017). Berdamai Dengan Hipertensi. Jakarta: Bumi Medika.

Suoth, Meylen., Hendro Bidjuni., Regius T. Malara. (2015). hubungan gaya hidup dengan penyakit hipertensi. 